\title{
Prolegômenos à antropologia filosófica: histórico de um programa de pesquisa
}

\author{
Prolegomenon to the philosophical \\ anthropology: history of a research program
}

\author{
Cleber Ranieri Ribas de Almeida \\ Professor da Universidade Federal do Piauí \\ Doutorando em Filosofia pela Universidade de São Paulo
}

Resumo: Este artigo pretende reconstituir a história da Antropologia Filosófica como disciplina acadêmica e como programa de pesquisa. Tal reconstituição será feita a partir da tese de Odo Marquard, segundo a qual há uma contraposição indissolúvel entre Antropologia Filosófica e Filosofia da História. O propósito é distinguir entre "humanismo" e Antropologia Filosófica. Ambos têm história conceitual, trajetória etimológica e programas disciplinares absolutamente dissociados. O "humanismo" e as filosofias do homem estão ancorados numa Filosofia da História. Em contraposição, a Antropologia Filosófica está ancorada numa Filosofia da Natureza. Portanto, contrariamente ao que afirma parte significativa da bibliografia especializada, "humanismo" e Antropologia Filosófica constituem programas de pesquisa absolutamente antitéticos. Por fim, para provar esta antítese, serão enumerados e caracterizados os princípios antropológicos e os imperativos metodológicos de investigação que definem o programa de pesquisa da Antropologia Filosófica.

Palavras-chave: Antropologia Filosófica; Humanismo; Odo Marquard. 
Abstract: In this paper I proposed to reconstruct the history of Philosophical Anthropology as an academic discipline and as a research program. This reconstruction was made from the Odo Marquard's thesis according to which there is an opposition between Philosophical Anthropology and Philosophy of History. The purpose was to distinguish between "humanism" and Philosophical Anthropology. Both have conceptual history, etymological background and disassociated disciplinary programs. The "humanism" and the philosophies of man are grounded in Philosophy of History. In contrast, Philosophical Anthropology is grounded in a Philosophy of Nature. Therefore, contrary to claims significant part of the relevant literature, "humanism" and Philosophical Anthropology are absolutely antithetical research programs.

Keywords: Philosophical Anthropology; Humanism; Odo Marquard.

\section{INTRODUÇÃO}

A definição cronológica exata acerca da origem da Antropologia é imprecisa. Podemos nos reportar a esta origem de duas formas: a primeira, mediante uma investigação acerca do uso da palavra "Antropologia" na história das ciências e da Filosofia. Neste caso, poderíamos estabelecer um critério filológico-conceitual quanto ao uso do termo e suas respectivas designações em cada contexto histórico. O filósofo Odo Marquard, em seu estudo intitulado "Zur Geschichte des Philosophischen Begriffs "Anthropologie", seit dem Ende des 18. Jahrhunderts"', publicado em 1965, identificou o uso pioneiro da palavra na obra Anthropologicum de Hominis Dignitate, Natura et Proprietatibus, de Magnus Hundt, em 1501. Diversos dos manuais que tratam do tema referem-se ao livro Psycologia Anthropologica Sive Animae Humanae Doctrina, de Otto Casmanns, publicado em 1594 e 1596 (Arlt, 2008; W. Keller, 1977). Em ambos os casos, conforme nos adverte Marquard, "o termo 'anthropologia' aparece como designação da 'psychologia' do ser humano em distinção ao vivente não humano" (Mar-

$1 \quad$ Este artigo foi traduzido para o espanhol como capítulo do livro Las Dificuldades con la Filosofia de la História. Cf. Odo Marquard. "Sobre la História del Concepto Filosófica de "Antropologia" desde Finales del Siglo XVIII". pp. 133-158. Pré-Textos, Valência, 2007. Todas as traduções subsequentes referentes aos textos de Marquard e Michael Landmann são minhas. 
quard, 2007, p.136). Ou seja, não se trata da designação mais geral que contemporaneamente atribuímos ao termo: a Antropologia como um empreendimento filosófico ou científico que visa responder à questão "que é o homem?". Para Marquard, o emprego pioneiro da palavra segundo a designação que hodiernamente concedemos se deu com a Antropologia de um ponto de vista pragmático (Anthropologie in Pragmatischer Hinsicht), de Immanuel Kant, publicado em 1798, porém, redigido para as lições proferidas no inverno de 1772-1773. Numa carta de 1773, endereçada a Marcus Herz, Kant manifesta claramente seu projeto de converter a Antropologia numa disciplina acadêmico-curricular (Kant, 1922, p. 145). É com o filósofo de Königsberg que a Antropologia inicia sua reviravolta ao «mundo da vida» e abre o caminho para o surgimento ulterior da fenomenologia.

A segunda forma de nos reportarmos à origem da Antropologia, para os fins que ora nos propomos, deve restringir-se ao aspecto filosófico desta disciplina. É esta acepção que investigaremos neste estudo. Referimo-nos, portanto, à Antropologia Filosófica stricto sensu, isto é, ao empreendimento que visa à síntese entre as ciências empíricas do homem e a fenomenologia. Neste caso, recaímos em mais uma controvérsia: teria a Antropologia Filosófica sua origem em 1928 quando veio a lume a obra de Max Scheler, Die Stellung des Menschen im Kosmos ou, contrariamente, em sua acepção estrita, esta teria surgido no primeiro quinquênio do século XIX com a denominada Escola Alemã de Antropologia? Odo Marquard intenta provar em seu exaustivo e sistemático estudo que a história do conceito filosófico de Antropologia antecede ao reverenciado livro de Max Scheler, e que os fundamentos desta Antropologia já estariam dados por autores desconhecidos - em sua maioria médicos - que publicaram entre 1798-1856. Seriam eles: "Metzger, Pölitz, Abicht, Wenzel, Görres, Funk, Liebsch, Fries, Troxler, Geitner, Suabedissen, Neumann, Schulze, Hillelbrand, Maine de Biran, Berger, Siegtwart, Choulant, Heusinger, Bonstetten, Weber, Rittel, Leupoldt, Burdach, Michelet, I.H.Fichte, Lotze" (Marquard, 2008, p.141) ${ }^{2}$.

2 A nota de fim n.60 (pp.247-250) apresenta-nos a discriminação exaustiva desses e outros autores com suas respectivas obras e ano de publicação. Trataremos de alguns deles conforme convenha às questões desenvolvidas ao longo do texto. Também Michael Landmann dedica um breve 
Marquard, portanto, recusa as hipóteses da origem da Antropologia Filosófica a partir das obras de Johann Gottfried Von Herder no livro Auch Eine Philosophie der Geschichte zub Bildung der Menschheit (Também uma Filosofia da História para a Formação da Humanidade, 1774) ${ }^{3}$, bem como a partir da Filosofia de Wilhelm von Humboldt, especificamente em sua obra não publicada intitulada Plan Einer Vergleichenden Anthropologie (Programa para uma Antropologia Comparada, 1797) ${ }^{4}$. Esta recusa ocorre porque, segundo o intérprete, as narrativas mitológicas da origem filosófica da disciplina teriam por propósito escamotear sua verdadeira origem naturalista e científica. O objetivo, neste caso, seria atribuir à tradição filosófica, e não às ciências médicas, os louros da invenção desta matriz disciplinar. Casos como o de Arnold Gehlen - cuja Antropobiologia concede créditos de precursor à J.G. Herder - seriam exemplos probantes de tais estratagemas narrativas.

Como sabemos, a narrativa hegemônica confere a Max Scheler o título de fundador da disciplina. De fato, ele não apenas nomeou como propôs um método para Antropologia Filosófica, qual seja: incorporar os avanços das denominadas ciências do homem - Fisiologia humana, Paleoantropologia, Etologia, Anatomia e Primatologia, por exemplo - ao estudo filosófico do humano. A partir destes elementos científicos propunha identificar os fatores que concedem unidade à espécie, independentemente das infinitas possibilidades de expressão

estudo catalográfico acerca desses autores da Escola Alemã de Antropologia: Cf. Landmann, Michael. De Homine. Man in the Mirror of his Thought. Part VI "German School Anthropology". 1962 (1979). pp. 281-332.

3 Herder, em escritos não publicados que datam de 1763, comprometia-se em realizar uma «Revolução Copernicana» de modo que sua Filosofia da História (geschichtsphilosophie) estivesse fundada numa Antropologia. Os quatro livros de sua Ideen Zur Philosophie der Geschichte der Menschheit (Ideias Para Uma Filosofia da História da Humanidade, 1784-1791) concebem o homem como o resultado final da criação. Para ele, o estudo do homem deveria valer-se de uma história natural. Daí a aproximação de Herder com a Histoire Naturelle de Buffon e com outros cientistas da natureza da época.

$4 \quad$ Já Humboldt centrou-se no estudo do «character» enquanto atributo do homem natural, moral e histórico. Segundo ele, o antropólogo deveria exibir a tríplice disposição em ser naturalista, historiador e filósofo, uma vez que o homem concentraria em si estes três caracteres (Marquard, 2007, p.209-239). 
da pluralidade cultural. Este seria o sentido estrito e cronologicamente demarcado da Antropologia Filosófica enquanto disciplina acadêmica e enquanto problema filosófico. Há, entretanto, uma Antropologia Filosófica em sentido lato, responsável direta pelo imbróglio conceitual com o termo "humanismo". Tal sentido define-se como uma hermenêutica da tradição filosófica ocidental. Seu propósito seria identificar o conteúdo antropológico subjacente em diversos clássicos da história da Filosofia. Ambos os sentidos - lato e estrito - compunham o programa da Antropologia Filosófica de Scheler, porém, direcionados a um único intuito: constituir uma autoimagem autônoma e integral do homem que não estivesse vinculada a mitos deístas, à metafísica ou à zoologia.

Tanto em sentido lato (hermenêutica antropológica do cânone) quanto em sentido estrito (fenomenologia biofilosófica da unidade do homem), a Antropologia Filosófica pretendia ser uma disciplina acadêmica em pé de igualdade às disciplinas clássicas (ética, estética, política e metafísica). À diferença que, em sentido estrito, ela se constituiu num problema filosófico cuja solução demandava diálogo permanente e inconclusivo com as ciências empíricas do homem. Quer dizer, configurava-se numa tentativa de síntese fenomenológica de tais ciências empíricas ao buscar por uma resposta acerca da unidade e singularidade do humano (Fischer, 2009; Marquard, 1965). Já em sentido lato, aproximava-se de uma hermenêutica antropológica do cânone, embora não de um cânone incontroverso, uma vez que cada intérprete elegia para si um conjunto de autores específicos os quais julgavam de maior relevância. Podemos comparar, por exemplo, as narrativas de Max Scheler (1926), Ernst Cassirer (1944), Sartre (1945), Heidegger (1947) e Groethuysen (1953), cada qual com uma perspectiva canônica distinta.

Seria de bom alvitre se pudéssemos acompanhar a reconstituição da história da Antropologia Filosófica segundo a versão de Marquard, não apenas porque ela explicita a contraposição entre a Antropologia Filosófica e a Filosofia da História desde Kant, mas porque tal versão nos oferece um retrato disciplinar deste programa de pesquisa. 
Este estudo subdivide-se, portanto, nos seguintes tópicos: 1) caracterização da origem da Antropologia Filosófica a partir da tríplice recusa às ciências matemáticas da natureza, à metafísica tradicional e à Filosofia da História; 2) reconstituição da narrativa histórico disciplinar da Antropologia Filosófica conforme a propõe Odo Marquard; 3) avaliação da tese marquardiana da contraposição "indissolúvel" entre Antropologia Filosófica e Filosofia da História; 4) enumeração e caracterização dos imperativos antropológicos e dos princípios metodológicos que conferem unidade ao programa de pesquisa da Antropologia Filosófica em seu sentido estrito.

\section{A TRÍPLICE RECUSA DA ORIGEM}

Os recortes histórico-longitudinais propostos pelos estudos de Groethuysen, Scheler, Brüning, Landmann e Cassirer (Marquard, 2007, p.134), reproduzem mutatis mutandis o modelo tipológico do último Dilthey. Dilthey, como sabemos, propunha uma teoria morfológica do antagonismo indissolúvel das visões de mundo e dos sistemas metafísicos. Segundo ele, toda mundividência resultaria da consciência histórica do presente e da pluralidade das experiências vitais. Daí a proposição de tipos históricos como instrumentos de síntese das mundividências. O uso deste recurso histórico-sociológico fora replicado pelos intérpretes da história antropológica da filosofia como uma tipologia das múltiplas formas preexistentes de autoconsciência do homem desde o início das civilizações. O "corte longitudinal histórico", ao constituir tipos sociológicos, facilitaria a classificação das múltiplas visões deístas, mitológicas e filosóficas do homem ao longo da História. Os tipos seriam representados por experiências vitais "na Antiguidade, na Idade Média e na época Moderna” (Marquard, 2007, p.234).

As taxonomias tipológicas das múltiplas filosofias do homem propostas por tais intérpretes, afirma Marquard, não deveriam ser identificadas como autêntica Antropologia Filosófica. Quer dizer, "aquelas filosofias interessadas de um modo central pelo ser humano" não se constituiriam, a rigor, em Antropologia 
Filosófica, sobretudo porque são modalidades específicas da Filosofia da História. A Antropologia Filosófica, assinala o autor:

[...] não engloba de nenhum modo todas as Filosofias para as quais o ser humano e o mundo da vida representam o tema central, senão entre elas unicamente aquelas que não são Filosofias da História e que, precisamente por este motivo, são Filosofias da 'natureza' do ser humano."(Marquard, 2007, p.138).

Portanto, não deveríamos denominar Antropologia Filosófica toda e qualquer teoria filosófica do fenômeno humano, mas tão somente aquelas que se tornaram possíveis mediante a "reviravolta ao mundo da vida", a recusa à Filosofia da História e a afirmação de uma fenomenologia empírico-científica da natureza como fundamento programático de investigação. Quer dizer, como disciplina acadêmica, a Antropologia Filosófica estabeleceu-se epistemologicamente a partir desse triplo processo de recusa: a recusa da Filosofia como "metafísica da escola tradicional", a recusa "das ciências matemáticas da natureza" (mathesis universalis) e a recusa da Filosofia da História enquanto guia de investigação do fenômeno humano. Esta tripla recusa ocorreu, como dissemos, mediante uma reviravolta ao mundo da vida, isto é, mediante a assimilação e apropriação do método fenomenológico:

[A Antropologia Filosófica] torn[ou]-se possível mediante o abandono da metafísica da escola tradicional e das ciências matemáticas da natureza, quer dizer, mediante uma 'reviravolta ao mundo da vida', a qual se torn[ou] fundamental mediante o 'retorno ao mundo da natureza', quer dizer, mediante a resignação da Filosofia da História (Marquard, 2007, p.149).

As três recusas, portanto, foram responsáveis pela fundação desta disciplina acadêmica e de seu programa de investigação filosófica. Desde então, não houve conciliação possível entre a Antropologia Filosófica estrita e as Filosofias da História.

Como podemos perceber, a narrativa de Marquard preteriu completamente o uso de tipologias históricas e cortes longitudinais semelhantes àqueles que encontramos nos estudos de Max Scheler, Ernst Cassirer e Michael Landmann. Em vez de 
uma hermenêutica antropológica do cânone, Marquard propôs uma história acadêmico-disciplinar. Para o autor, os cortes histórico-longitudinais foram úteis para promover o caráter sacro e perene da Antropologia Filosófica. Os tipos diltheysianos, por sua vez, foram incorporados porque coadunaram-se às tarefas tradicionais da Antropologia, tais como as teorias das diferenças naturais, a classificação das idades da vida, as raças, as distinções entre os seres orgânicos e inorgânicos, etc.

O caráter precursor da Escola Alemã de Antropologia, como dissemos, fora relegado por autores tardios como Scheler, Plessner e Gehlen porque estes não admitiam o caráter filosófico das obras de Medicina produzidas na Alemanha de meados do século XIX. Estaríamos, portanto, diante do processo de olvido de uma tradição relegada. Não se trata aqui propriamente de um esquecimento acidental, mas de uma recusa acintosa cuja finalidade seria evitar a dessacralização da Antropologia Filosófica, postulada hodiernamente como conhecimento do "eternamente humano" e do "eternamente filosófico". Contudo, a ideia da Antropologia Filosófica como "Filosofia fundamental" legisladora de todo conhecimento humano é recente, data da década de 1920. Ao expor as origens naturalistas desta disciplina, Marquard quer não apenas desmitificá-la, como também, torná-la historicamente determinada, além de visível a seus oponentes ${ }^{5}$.

Por conta dessa crença na Antropologia Filosófica como legisladora de todas as ciências e fundamento de toda Filosofia, diversas áreas do saber incorporaram de forma permissiva e anárquica o cognome "Antropologia". A "Antropologia", passou a ser concebida como ciência aplicada, multiplicando-se em "Antropologia médica", "Antropologia pedagógica", "Antropologia religiosa", "Antropologia teológica", "Antropologia cristã", "Antropologia cultural", "Antropologia histórica", "Antropologia social", "Antropologia das ciências humanas", "Antropologia psicológica", "Antropologia política", "Antropologia fenomenológica", "Antropologia dialética", "Antropologia basal", etc.

$5 \quad$ Percebe-se que Marquard negligencia, recusa ou dá pouca relevância, às obras de Schopenhauer e Goethe no que diz respeito ao desenvolvimento da disciplina. 
Desde a década de 1920, a Antropologia Filosófica passou a ser aceita como antropologia fundamental:

A Antropologia, no centro da filosofia atual, não só [passou a] designa[r] cada vez mais uma secção [isto é, uma disciplina acadêmica], mas uma senha filosófica de natureza enfática: 'Antropologia' [passou a] designa[r] [desde então] o tema central que deve ser abordado desde um ponto de vista filosófico; converte-se em autêntico sinônimo da filosofia em geral". (Marquard. 2007, p.133).

Como ocorreu essa difusão e apropriação da Antropologia por outras áreas de estudo? Qual a origem histórica de tal mixórdia taxonômica? Atualmente, qualquer domínio da realidade que possamos investigar é concebido como portador de "fundamentos antropológicos" implícitos ou explícitos. Como dissemos, este fenômeno da apropriação difusa de uma palavra "mágica" decorreu da sacralização da Antropologia. O mesmo se dera no uso licencioso do termo "humanismo" no início do século XX. Para responder a essas questões, Marquard propõenos reconstituir historicamente a história disciplinar da Antropologia Filosófica. É o que faremos agora.

\section{ODO MARQUARD E A ANTROPOLOGIA FILOSÓFI- CA COMO NEGAÇÃO DA FILOSOFIA DA HISTÓRIA}

O livro Antropologia Desde um Ponto de Vista Pragmático, de Immanuel Kant, fora a obra pioneira no que diz respeito à reviravolta ao mundo da vida no longo processo que abriu caminho para a gênese da Antropologia Filosófica. Segundo Marquard:

A reviravolta de Kant até a Antropologia está, pois, relacionada com a formação do ponto de vista da crítica da razão segundo a qual a metafísica da escola tradicional só se ocupa de 'cosas mentales' enquanto as ciências matemáticas da natureza só se ocupam de 'fenômenos'. Portanto, o mundo da vida humana que não se pode reduzir à totalidade sem a realidade do 'mundo do entendimento', nem à totalidade sem a realidade do 'mundo dos sentidos' [...] esse mundo da vida também exige uma teoria filosófica. Por essa razão, Kant também define a Antropologia Filosófica de um modo central como 'conhecimento do mundo' que não cabe alcançar nem pelo pensa- 
mento metafisicamente puro, nem pelo experimento cientificamente exato, senão somente [...] pela experiência cotidiana (Marquard, 2007, pp. 137-138).

A Antropologia kantiana, portanto, tinha como ponto de partida a experiência cotidiana da vida pré-filosófica. Ao reconhecer a necessidade premente dessa Filosofia do mundo ordinário e cotidiano, Kant desobstruiu a passagem para o surgimento de outras filosofias do mundo da vida. Desde então, as filosofias do Lebenswelt floresceram, dentre elas, a Filosofia da História, a qual seria uma:

Filosofia do destino do homem desenvolvida mediante a teoria da liberdade com seu 'fim final' e mediante a teoria do mundo histórico da vida como 'a mediação' progressiva desse fim final (Marquard, 2007, p. 139).

Ora, se a reviravolta em direção ao mundo da vida não fora um movimento peculiar à Antropologia Filosófica, então tal movimento não teria o atributo de definir a singularidade da disciplina. Tal singularidade manifestar-se-ia verdadeiramente na recusa à Filosofia da História. Em verdade, como enfatiza Marquard, desde que surgiram as filosofias do Lebenswelt, a Antropologia Filosófica passou a desempenhar o papel de "grande alternativa à Filosofia da História", reforçando sua imagem de "Filosofia fundamental" redentora, porém, sempre ocupando um lugar marginal no mainstream acadêmico e filosófico. Por esta razão, a Antropologia kantiana fora relegada à condição de simples parergon diante da Filosofia da História [Ideia de uma História Universal de um Ponto de Vista Cosmopolita], da Ética ou da Teoria do Conhecimento proposta por Kant.

Por outro lado, Kant distinguiu claramente entre Antropologia "fisiológica" e Antropologia pragmática:

Uma doutrina do conhecimento do ser humano sistematicamente composta (antropologia) pode ser tal do ponto de vista fisiológico ou pragmático. - O conhecimento fisiológico do ser humano trata de investigar o que a natureza faz do homem; o pragmático, o que ele faz de si mesmo, ou pode e deve fazer como ser que age livremente (Kant, 2009, p. 21). 
Kant jamais admitiu que a resposta dada pela Antropologia à questão - "que faz o homem de si mesmo?" - fosse "fisiológica", isto é, fosse dada a partir das representações naturalistas que concebem o homem como autômato, inexoravelmente dominado pelas forças orgânico-corporais. A resposta, diz-nos Kant, deve ser "pragmática", isto é, deve ter como ponto de partida o que o homem faz, pode e deve fazer de si mesmo, enquanto criatura que atua livremente. Tal reformulação trouxe em si uma mudança de perspectiva. A Antropologia deveria transitar do mundo da vida para uma Filosofia da História fundada no livre-arbítrio do homem, isto é, uma Filosofia do destino do homem compreendido como animale rationabile que ainda não realizou como espécie seu destino histórico racional.

A posição subalterna da Antropologia, desde a reviravolta kantiana, prorrogou-se até o advento do idealismo alemão, quando a ideia relativa ao "progresso infinito" da história passou a ser severamente questionada, e, finalmente, substituída pela Filosofia romântica da natureza. A visão da história como um horizonte infinito desprovido de esperança tivera como lugar-tenente a ideia a-histórica da natureza, não como essência metafísica, fenômeno ou mathesis universalis, mas como vitalidade, força espontânea. Durante o romantismo, portanto, a Antropologia deslocou-se de sua posição subalterna em relação à Filosofia da História ao transformar-se na antípoda do projeto kantiano, isto é, ao tornar-se uma Antropologia "fisiológica". Por "fisiológica" não se entendia aí uma Antropologia de caráter "puramente científico-natural" (Marquard, 2007, p. 140), tampouco uma Antropologia destituída de significação filosófica, mas uma "Filosofia da natureza do ser humano" (Marquard, 2007, p. 140), isto é, uma Fisiologia filosoficamente ativa acerca da condição orgânica e espiritual do homem.

Assim, a Antropologia tornou-se assunto dileto de médicos e anatomistas a tal ponto que o estudioso Franz von Paula Gruithuisen reivindicou em 1810 que "essa teoria" tinha que "sair das mãos de anatomistas e médicos" (Gruithuisen, 1810). Marquard, então, reitera o papel precursor destes autores em relação à Antropologia Filosófica do século XX: 
Assim, os médicos se tornaram competentes na Filosofia da natureza do ser humano; e justo por esta razão, a Antropologia médica do romantismo forma parte dos ancestrais filosoficamente relevantes da Antropologia contemporânea; ela antecipa inclusive teses: 'Conforme as suas forças físicas[...] logo se descobrem no ser humano carências, em virtude das quais não suporta nenhuma comparação com os animais [...] Mas em virtude do seu espírito - que é 'um ser absolutamente diverso da natureza' e ' jamais aparece' - se eleva sobre a natureza (Marquard, 2007, p. 141). ${ }^{6}$

Ao citar Ennemoser, Marquard pretende provar documentalmente que a Antropologia Filosófica moderna nasceu da recusa, não apenas da Filosofia da História, mas também de sua própria tradição.

A partir daí, o autor segue sua cronologia analítica ao centrar a atenção na importância de Feuerbach para a cisão entre Antropologia e Teologia. À época de Feuerbach, a relação entre a Teologia e a Antropologia tornou-se dilemática: ou a Antropologia se convertia em uma "preparação" para a revelação teológica, ou contrariamente, como propôs Feuerbach, ela se posicionaria como uma negação da Teologia "absolutamente outra" antropólogos de sua época, em sua maioria, autores que concebiam a natureza como base do ser humano e objeto universal da Filosofia. Desde então, a Fisiologia passou a ser vista como parte constitutiva da ciência universal do homem, a Antropologia. Daí que, como assinala Marquard, Feuerbach tenha se situado "totalmente na tradição das antropologias da Filosofia romântica da natureza [...] sua importância extraordinária resid[ia], sobretudo, no fato de ter defendido essa tradição antropológica expressamente contra Hegel" (Marquard, 2007, p. 142).

Ao atacar a Antropologia, Hegel obrigou-a a recorrer à Filosofia da História de modo que esta passasse a subjugar àque$6 \quad$ A citação que Marquard aí insere é de Bonn Joseph Ennemoser. Consideraciones Antropológicas. (1828).

7 Marquard refere-se ao apreço que o flanco existencialista da teologia protestante tem por Feuerbach desde Kierkgaard. De fato, a relação entre Antropologia e teologia torna-se mais tensa entre os teólogos protestantes porque estes estabeleceram uma relação mais receptiva e aberta com a Filosofia secular. Sobre esta questão em geral, e sobre Feuerbach em particular, recomendo a leitura de Wolfhart Pannenberg. (1985) Anthropology in Theological Perspective. The Westminster Press, Philadelphia. pp. 276-281. 
la. É bem conhecida a sua definição do "espírito subjetivo" na Primeira Secção do volume III da Enciclopédia das Ciências Filosóficas. Ali, Hegel afirma que "O espírito subjetivo é: A) Em si ou imediato. Assim ele é a alma ou o espírito-da-natureza; objeto da Antropologia" (Hegel, 2011, p. 37, § 387). O repúdio hegeliano à Antropologia de sua época expressou-se, entretanto, com maior veemência na Introdução a este tomo da Enciclopédia:

O conhecimento do espírito é o mais concreto, portanto o mais alto e o mais difícil. "Conhece-te a ti mesmo" — esse mandamento absoluto não tem em si, nem onde se apresenta historicamente como expresso, a significação de ser apenas uma auto-conhecimento [...] mas tem a significação do conhecimento do verdadeiro homem, como [também] do verdadeiro em si e para si — da essência mesma enquanto espírito. Tampouco tem a Filosofia do espírito a significação do que se chama conhecimento dos homens, que se dá ao trabalho de pesquisar nos outros homens igualmente as particularidades [Besonderheiten]; paixões, fraquezas, que se dizem ferrolhos do coração humano. [É isso] um conhecimento que de um lado só tem sentido na pressuposição do conhecimento universal, do homem, e portanto essencialmente do espírito; de outro lado, ocupa-se das existências contingentes, insignificantes, não verdadeiras do espiritual, mas não impele até ao substancial, ao espírito mesmo (Hegel, 2011, p.7, § 377).

Para Hegel, a Antropologia médica e anatômica — "fisiológica" - não atingiria o nível mais elevado e necessário do universal, do substancial, uma vez que permanecia na superfície das particularidades insignificantes, das existências contingentes e não verdadeiras. É neste aspecto que Marquard nos adverte que a crítica de Hegel à Antropologia assumiu o aspecto de uma apropriação, uma vez que esta mesma Antropologia passou a fazer parte de sua Filosofia, porém, subjugada pela Filosofia da História, esta sim, substancial e universal. Em razão disso, Marquard assinala que "o intento hegeliano de adaptar a Antropologia à Filosofia da História implic[ou] a degradação da Antropologia" (Marquard, 2007, p. 143). Esta apropriação crítica da disciplina fora também uma resposta ao romantismo enquanto Filosofia centrada unicamente no espírito natural e suas determinações imediatas, ou como afirma Marquard, uma

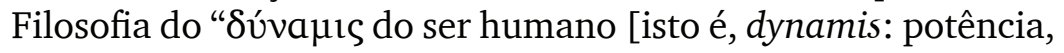
capacidade ativa ou passiva], insuficiente para afrontar os problemas de sua realização histórica" (Marquard, 2007, p. 143). Não nos resta dúvida de que a relação entre a Filosofia da His- 
tória e a Antropologia quedou numa disjunção irremediável. A apropriação crítica de Hegel fora uma tentativa de adaptar a Antropologia à Filosofia da História, o que, para Marquard, seria uma tarefa impossível.

Já os casos de Wilhelm Dilthey e Jacob Burkhardt exemplificaram o inverso, isto é, uma tentativa de adaptar a Filosofia da História à Antropologia. Dilthey afirmou que "só a história diz ao homem o que ele é" ao mesmo tempo em que sustentava: "a natureza do homem [...] é sempre a mesma" (Dilthey, apud Marquard, 2007, p. 143). Como podemos deduzir, não há possibilidade lógica e filosófica de coexistência de dois enunciados desta natureza: ou se postula uma Filosofia da Natureza imutável do homem, ou, pelo contrário, postula-se uma Filosofia da pluralidade e mutabilidade da experiência histórica particular. Segundo Marquard, tanto Dilthey quanto Burkhardt, ambos "delegados da consciência histórica", acreditavam na imutabilidade da natureza humana como um "enigma da vida", apesar da natureza cambiante da história. O caso de Dilthey fora mais edificante porque ele se abriu à possibilidade de diálogo com a Antropologia e com a Psicologia ao buscar uma fundamentação para as Ciências do Espírito na Filosofia da Natureza, sobretudo a Filosofia da Natureza de Goethe ${ }^{8}$. Ora, se a verdade sobre o homem é sua natureza imutável, como assinalava Dilthey:

[...] o elemento do espírito suscetível à mudança histórica só pode ser definido mais além da questão da verdade, como expressão de um sentimento vital, quer dizer, como "concepção de mundo". O nome "Antropologia" oculta também desde agora, esta renúncia à questão da verdade. Por conseguinte, "a Antropologia" pode adquirir em qualquer parte o significado de "explicação da concepção de mundo vigente (Marquard, 2007, p. 144).

Para conciliar a Antropologia de sua época à Filosofia da História, Dilthey fora obrigado a abdicar da questão da verdade, relativizando-a segundo a ideia da pluralidade de "concepções de mundo". Ora, para Marquard não seria possível

$8 \quad$ Sobre esta relação de Goethe com as ciências da natureza recomendo o livro de Maria Filomena Molder, O Pensamento Morfológico de Goethe. Lisboa, Casa da Moeda, 1995. Sobre a assimilação das ciências naturais como fundamento das ciências do espírito em Dilthey conferir a quarta secção do tomo II da Introdução às Ciências Humanas. pp. 401-486. 
conciliar a pluralidade à ontologia humana, na mesma medida em que não seria possível conceber o imutável e o cambiante numa mesma Filosofia. Ou esposamos uma Filosofia da Natureza ou uma Filosofia da História.

Neste aspecto, o caso da crítica de Heidegger à Antropologia Filosófica (Heidegger, 1996, p.176-184, § 37) fora igualmente sintomático. Parte significativa dos intérpretes reconhece o apego inabalável do filósofo ao princípio da Imago Dei próprio à Teologia judaico-cristã. Embora tenha incorporado diversas das descobertas da biofilosofia de Uexküll, Heidegger não admitia a legitimidade da Antropologia "fisiológica" como fundamento para a Ontologia Existencial. A negação radical da Filosofia da Natureza, decerto, provocou a dissidência tardia de autores do círculo heideggeriano, como foram os casos de Karl Löwith, Binswanger e H.G. Gadamer, os quais passaram a advogar expressamente em favor de uma Antropologia "fisiológica".

Não obstante, casos de "conversão" à Filosofia da Natureza constituíram-se exceções à regra. Exemplos como os de Lukács, Sartre e o último Husserl dos anos 1930 — todos adeptos à Filosofia da História — foram predominantes. Lukács, por exemplo, ao referir-se à "mudança de rumo" que Feurbach impôs à história da Filosofia, lamentava que tal mudança tivesse transformado "a filosofia numa 'antropologia' e, assim, tivesse "conden[ado] o homem a uma objetivação fixa". Este seria "o grande perigo de todo 'humanismo' e do "ponto de vista antropológico" que ele ensejava, qual seja: abolir toda "trancendência" e toda possibilidade de conceber o homem "dialético", isto é, histórico (Lukács, 2003, p.372).

Todos esses exemplos nos comprovam a lógica binária entre Antropologia Filosófica e Filosofia da História. Por isso, como assinala Marquard, a visibilidade da Antropologia Filosófica ocorreu em épocas nas quais a Filosofia da História estava em declínio. A Antropologia Filosófica do século XX representou, portanto, "a expressão de uma crise de confiança na História e sua Filosofia". Tal crise pode ser comprovada por três fenômenos:

1) O livro de Max Scheler - A Posição do Homem no Cosmos (1928) - fora unanimemente apontado como autêntico pioneiro da Antropologia Filosófica contemporânea. Isto é 
sintomático porque dentre as muitas filosofias do homem surgidas na década de 1920 — incluindo os "humanismos" — a obra de Scheler se distinguiu das demais por não conceber o homem em termos históricos, mas em termos de uma Filosofia da natureza. A máxima de Helmuth Plessner "sem uma Filosofia da Natureza, nenhuma filosofia do homem" comprova que a Antropologia Filosófica, desde a origem, estava mais suscetível ao diálogo com as ciências empíricas do homem do que com as filosofias do homem propriamente. Esta demarcação cronologicamente exata do surgimento da Antropologia Filosófica atuou, portanto, como um cordão sanitário em relação às ideologias humanistas - em sua maioria vinculadas a uma dada Filosofia da História - bem como em relação às filosofias do homem (isto é, aquelas Filosofias do homem destituídas de uma Filosofia da natureza). E mais do que isso, atuou como um cordão sanitário que faz desaparecer, num gesto de prestidigitação filosófica, a tradição empírica desta disciplina, qual seja, a Escola Alemã de Antropologia.

2) A crise de confiança na Filosofia da História no primeiro quinquênio do século XX expressou-se também na crescente influência da Antropologia de Arnold Gehlen. A despeito de sua filiação ao nazismo - e contrariamente ao que ocorrera com autores como Carl Schmitt e Martin Heidegger —, Gehlen não sofreu qualquer condenação axiológica ou política em sua obra. Pelo contrário:

Torn[ou]-se cada vez mais atrativa, precisamente, aquela teoria do homem que — em conexão com Herder — radicaliz[ou] a abordagem de Scheler, abandonando suas teses sobre o Espírito e orientando-se em geral até uma Filosofia da natureza do homem: esta interpreta[va] todas as suas realizações - incluindo o espírito - como 'descargas' de sua situação natural deficiente, e a cultura como um arranjo cujo único objetivo [era] evitar permanentemente a morte: os problemas do homem com a natureza tornaram-se exemplos da história. Assim, pois, a Antropologia contemporânea não só começa, mas também se consuma sob o signo do 'retorno à natureza'. Quando o ‘espírito' pareceu demasiado 'impotente' e a história demasiado irracional para ter um sentido a partir de si mesma, não h[avia], senão, a natureza para conferir a ambos este sentido. Quando o homem já não se defin[ia] mais desde o ponto de vista da Filosofia da História, [...] então não ha[via] mais escolha que o defina" (Marquard, 2007, pp.147-148). 
A via de Gehlen, ao optar pela radicalização da abordagem de Scheler - isto é, ao conceber o espírito enquanto uma das resultantes das "descargas" vitais do homem - era uma via que entronizava a natureza como único ente determinante na definição fenomenológica do humano. Daí que, o livro de Gehlen, dentre as três obras matriciais da Antropologia Filosófica, implicasse na mais radical recusa à Filosofia da História. É o caráter radical desta recusa que explica o seu sucesso editorial e filosófico.

3) A crise de confiança na Filosofia da História desde o advento da Antropologia Filosófica no século XX pode ser atestada pelo surgimento de várias "Antropologias" neste século. Uma vez que a Filosofia da História tenha perdido sua capacidade de responder às questões hodiernas, nada mais natural que fosse substituída pela Antropologia, esta sim, um fundamento confiável. Cada ciência particular passava a elaborar a sua própria Antropologia. Marquard adverte-nos que somente as ciências desprovidas de uma efetiva Filosofia da História passaram a demandar uma Antropologia fundamental:

Não é um azar que hoje em dia apelem à Antropologia justo aquelas ciências cuja validade na época moderna mantém uma relação disjuntiva com a validade da Filosofia da História e que, por regra geral, se tornam filosoficamente ativas como compensação a uma Filosofia da História incapaz de cumprir com as suas exigências: trata-se, por exemplo, da Pedagogia, da Teologia e da Medicina. E sem dúvida, tampouco é um azar que a Antropologia Filosófica, em seu intento de atenção à história — desde uma perspectiva 'pós-ciências -humanas', por assim dizer - não possa ser interpretada a partir de então pela Filosofia da História, mas tão-somente pela não-Filosofia da História: pela Sociologia e pela Teologia bíblica ou laica da situação dialógica. Ambas as teorias da história - por contrárias que sejam - 'simpatizam com a Antropologia' — posto que ambas se estabelecem mediante o abandono do conceito de história próprio da Filosofia da História (Marquard, 2007, pp.148-149).

O verbete de Habermas, de 1958, Philosophische Anthropologie (redigido sob orientação de Erich Rothacker), foi nesta mesma direção ao abordar a relação entre a Antropologia Filosófica e suas fontes empíricas: trata-se de uma "ciência reativa". Entretanto, Habermas atentava apenas para a primeira via da relação entre as partes. Neste caso, haveria uma relação apropriativa da Antropologia Filosófica em relação às ciências empíricas 
do homem na forma de síntese, enfeixamento e busca de unidade na pluralidade de abordagens destas ciências. A Antropologia Filosófica seria aí uma ciência de refração, filtragem e unidade das ciências do homem. Por outro lado — numa segunda via haveria uma relação de elaboração antropológica pelas demais ciências, fossem humanas ou naturais. Cada uma destas ciências é autárquica quanto à elaboração de sua própria Antropologia: converter-se-iam, portanto, em ciências "filosoficamente ativas". Daí resultaria aquela proliferação de Antropologias às quais nos referimos anteriormente, isto é, resultaria da falência da Filosofia da História no campo de cada ciência em particular.

\section{POSSIBIIDADES DE RECONCILIAÇÃO ENTRE ANTROPOLOGIA FILOSÓFICA E FILOSOFIA DA HISTÓRIA}

A oposição entre Antropologia Filosófica e Filosofia da História, segundo Marquard, permaneceu inadvertida até a publicação de seu ensaio. O autor faz então duas considerações acerca da oposição: a condição antitética entre as duas Filosofias pode ser admitida como vantajosa para a Antropologia Filosófica, ou, pelo contrário, pode-se tentar superar a oposição a partir da proposição de um projeto de conciliação e diálogo entre as duas tradições.

A primeira consideração parte do pressuposto de que a Antropologia Filosófica está numa condição hegemônica em relação à Filosofia da História. Isto não nos surpreende em um artigo redigido em 1965 quando os debates "humanistas" estavam em voga por toda a Europa. A admissão da oposição para a Antropologia Filosófica seria, assim, extremamente vantajosa ou, como afirmou Michael Landmann, seria uma oportunidade. A perspectiva antropológica "voltada para a natureza e para o homem - concebido como creatura criatrix" - atuaria como um agente de "liberação da obsessão monista da Filosofia da História e sua crença errônea numa cultura absoluta, abrindo seu sensório à pluralidade" (Marquard, 2007, p.150). Ou seja, para Landmann e Marquard, a oposição pública entre ambas as Filosofias seria válida porque tornaria explícito o papel da Antropologia Filosófica como "guardiã da pluralidade". Esta seria a sua vantagem. 
Como sabemos, o ideário epistemológico da Antropologia Filosófica como Filosofia pluralista, multidisciplinar, e como herdeira da tradição dos médicos e anatomistas alemães de meados do século XIX fora retomado pelo monumental projeto de HansGeorg Gadamer e pelo médico Paul Vogler no compêndio intitulado Nova Antropologia, publicado no fim dos anos 1960. Segundo Marquard, esta obra marcou o tardio e definitivo giro antropológico de Gadamer em ruptura com a escola heideggeriana:

o nome Antropologia reforça ali [no compêndio organizado por Gadamer e Vogler] não só a liberdade do homem para ser aquilo que constitui cada um à sua maneira, mas também a liberdade das diversas ciências para expressar-se, cada uma à sua maneira, sobre o ser humano: tal é a tendência da 'Nova Antropologia' que procede da velha tradição antropológica (Marquard, 2007, p. 151).

O projeto monumental de Gadamer \& Vogler, portanto, deve ser interpretado como uma exitosa tentativa de reconstituir os fundamentos científico-naturais da Antropologia Filosófica desde a sua origem na Escola Alemã de Antropologia. Trata-se da atualização ou reconstituição de um paradigma perdido. Tal reconstituição poderia ensejar a reconciliação de todas as Antropologias "filosoficamente ativas" e, ainda, pôr as especialidades, sejam empíricas, sejam filosóficas, em pé de igualdade.

A segunda consideração — referente à possibilidade de superar a oposição - sugere um projeto de conciliação e diálogo entre as duas tradições, Antropologia Filosófica e Filosofia da História. É preciso, para tanto, crer que esta diaphonia seja passível de solução, entendendo que a Antropologia possa ser concebida como um momento da Filosofia da História, ou, contrariamente, que a Filosofia da História venha a ser um momento da Antropologia Filosófica. Em Hegel, como vimos, a Antropologia, embora subjugada, constituía-se num ponto de

$9 \quad$ Marquard refere-se à enciclopédia denominada Nova Antropologia, organizada por H.G.Gadamer e o pelo médico Paul Voegler. Por alguma razão que me é alheia, surpreendentemente, esta obra foi oito anos depois de sua publicação alemã, em 1977, integralmente traduzida e publicada no Brasil (Edusp). É composta por sete volumes: Vols. I e II: Antropologia Biológica; Vol. III. Antropologia Social; Vol. IV. Antropologia Cultural; Vol. V. Antropologia Psicológica; Vol. VI e VII. Antropologia Filosófica. 
partida para o universal histórico. Marquard vê nos trabalhos "quase-hegelianos" de Adorno e Horkheimer o intento renovado de conciliar estas duas tradições a partir da "Antropologia dialética". O homem enquanto conceito-limite de uma época burguesa não existiria senão como utopia que precisa apelar para conceitos anti-históricos e, assim, reivindicar seus ideais. Percebeu-se, portanto, que a perspectiva natural do ser humano poderia atuar como um antídoto às quantidades demasiadamente grandes de utopia das Filosofias da História. Esta lição permitiu a esta tradição moderar sua utopia do impossível para uma "arte do possível".

Outro projeto de reconciliação fora proposto por Michael Landmann. Em Landmann, encontramos um quadro sistemático da Antropologia tanto em seu sentido lato - isto é, enquanto uma hermenêutica antropológica do cânone, conforme podemos observar em De Homine: Man in the Mirror of his Thought quanto em seu sentido estrito (a partir da proposição de uma síntese empírico-metafísica da unidade do homem, conforme verificamos em Antropología Filosófica: Autointerpretacion del Hombre en la Historia y en el Presente e em Fundamental Anthropology).

Apesar de ser identificado aqui como um comentador da tradição da Antropologia Filosófica strictu sensu, Landmann pode ser também concebido como um teórico da disciplina. Seu esforço teorético, razoavelmente exposto no livro Fundamental Anthropology, resume-se em conciliar as tradições da Antropologia cultural anglo-francesa à Antropologia Filosófica. $\mathrm{O}$ autor as concebe como "ciências gêmeas". Para Landmann, as Antropologias da década de 1920 (as Filosofias da Existência, a Lebensphilosophie e a Antropologia Filosófica) são expressões do "espírito objetivo".

As teses do autor gravitam em torno de dois pontos. O primeiro diz respeito ao modo de conceber estas Filosofias como parte expressiva das "múltiplas faculdades do Espírito". Como enfatiza Ze'ev Levy no prefácio a esta obra, Landmann não estaria interessado em concentrar suas interpretações em um único pensador particular; preferiu dedicar-se ao estudo 
das disciplinas e seus problemas de modo a correlacioná-los numa compreensão holística do Espírito:

A tarefa real da Filosofia [...] consiste em confrontar concepções diferentes e opostas de uma esfera à outra no sentido de guiá-las [...] para uma melhor reciprocidade e compreensão mútua. A saúde das ideias alcança sua mais perfeita expressão não nas ideias como tais, mas na relação entre elas (Landmann, 1982, p. xiii).

Como afirma o próprio Landmann, "o método de contraste força-nos a ir além das teses explícitas dos pensadores para adentrarmos uma rede de categorias (categorial networks) do espírito" (p. xiii, Fundamental Anthropology). Este ponto explicita a filiação de Landmann à herança diltheysiana da história das ideias em sua busca por um espírito sub specie temporis.

O segundo ponto de gravitação dos esforços teoréticos de Landmann orbita em torno do conceito de Anthropina, um neologismo que reabilita uma palavra grega para expressar as propriedades distintivas do homem. Por Anthropina definem-se "as estruturas básicas atemporais da existência humana imutavelmente fixadas" (1982, p.125). O sistema da Anthropina "aplica-se ao todo; não pode explicar os particulares". Em seu Antropología Filosófica: Autointerpretacion del Hombre en la Historia y en el Presente, Landmann, ao tratar da Antropologia biológica, define Anthropina como:

o homem [...] se diferencia do animal não em todas as coisas, senão somente em algumas características, talvez em uma única característica. A esta característica chamamos anthropinos. Os anthropinos mais diferenciais têm sido assinalados pelos pensadores no curso dos séculos. Só o homem, tem-se dito, anda ereto, só ele tem mãos. $\mathrm{Ou}$, tendo em conta as semelhanças exteriores com o animal, se busca o anthropino no interior: só ele conhece o bem e o mal, sente vergonha, pode rir e chorar (Plessner), pode negar (Hans Kunz), guarda o passado, se dirige ao futuro (Buber), sabe que deve morrer, tem capacidade de suicídio (Rozensweig-Ehrenberg); ou: só ele pode pensar, só ele cria idiomas, utensílios, cultura em geral (Landmann, 1961, pp.170-171).

Como podemos perceber, o conceito de anthropinos, enquanto um conjunto de insígnias características do homem, 
constitui-se, ele próprio, uma tentativa de conciliar Antropologia Filosófica e Filosofia da História, sobretudo porque os caracteres culturais e anímicos se igualam aos caracteres biológicos e corporais na busca por uma ontologia empírica do homem.

Apesar destes esforços exemplares de conciliação propostos - implícita ou explicitamente - por autores como Horkheimer \& Adorno, Landmann e Gadamer ${ }^{10}$, o pathos do ensaio de Marquard nos sinaliza para a impossibilidade de conciliação entre esses dois programas de investigação filosófica. $\mathrm{O}$ movimento pendular da História da Filosofia — da natureza à história e da história à natureza - perdura até os nossos dias. É em razão deste ir-e-vir que, atualmente, assistimos ao tímido retorno da Antropologia Filosófica na obra de autores como Peter Sloterdijk, Bernhard Waldenfels, Joachim Fischer, Eibl-Eibesfeldt e Michael Tomasello. A conciliação, contudo, não pode ser concebida como um processo de redenção filosófica da própria Filosofia. Ela é apenas um desafio posto ante a interpretação marquardiana da história da Antropologia Filosófica como mera disciplina acadêmica.

Por outro lado, o diagnóstico de Marquard quanto à necessidade de conciliação negligencia o fracasso ulterior da Antropologia Filosófica como disciplina universitária para além das fronteiras germânicas. Se a estratégia de autopromoção e difusão desta disciplina resumia-se em apresentar-se como uma "Filosofia fundamental" ou como conhecimento do "eternamente humano", este estratagema retórico falhou. Como disciplina, a Antropologia Filosófica stricto sensu sofreu - sobretudo nos meios universitários periféricos - um processo de subsunção ao ser confundida erroneamente com os "humanismos", com as Filosofias da Existência e com as filosofias do homem. Em meio

$10 \quad$ Outro esforço de unificação pode ser observado no empreendimento de Edgar Morin e Massimo Piattelli-Palmarini ao organizarem um simpósio denominado "A Unidade do Homem" em 1974. Os textos e palestras proferidas por filósofos, biólogos, sociólogos, etólogos, psiquiatras, psicólogos, médicos e biofísicos, foram reunidos e publicados em três volumes. Cf. MORIN, Edgar; PALMARINI, Massimo Piatelli. (1978). A Unidade do Homem. Do Primata ao Homem. Continuidades e Rupturas. (Vol.1); A Unidade do Homem. O Cérebro Humano e seus Universais. (Vol.2); A Unidade do Homem. Para uma Antropologia Fundamental. (Vol.3). São Paulo: Cultrix 
a esta mixórdia, o caráter naturalista e biofilosófico da disciplina fora submetido a um processo sub-reptício de prestidigitação. É o que podemos observar nos manuais propedêuticos "humanistas" (Nogare, 1985; Agosti, 1970; Etcheverry, 1975). Esta subsunção anulou as possibilidades de assimilação criativa do cânone da Antropologia Filosófica stricto sensu para além dos assentos acadêmicos alemães. A retórica pós-estruturalista da "morte do homem" e o triunfo das Filosofias Analíticas relegaram a disciplina a uma condição secundária, subalterna, quase excêntrica. Quer dizer, o problema da conciliação apontado por Marquard diz respeito tão somente ao ambiente universitário germânico, onde ainda se preserva uma compreensão rigorosa acerca do que é a Antropologia Filosófica.

\section{A UNIDADE METODOLÓGICA E ANTROPOLÓGICA DO PROGRAMA DE PESQUISA DA ANTROPOLOGIA FILOSÓFICA}

Uma vez expostas (i) a narrativa histórica acerca da origem disciplinar da Antropologia Filosófica, (ii) a relação antitética desta disciplina com a Filosofia da História e (iii) a impossibilidade de conciliação entre ambas, passaremos agora a identificar os princípios antropológicos e os imperativos metodológicos de investigação que definem o programa de pesquisa da Antropologia Filosófica stricto sensu. Como veremos, serão enumerados dez princípios/imperativos de investigação conforme eles se apresentem na literatura canônica. Devo advertir de antemão que a enumeração destes itens - postos em ordenação hierárquica de relevância, isto é, dos imperativos antropológicos aos princípios metodológicos — não pretende ser exaustiva; visa tão somente apontar os fundamentos onipresentes nos textos clássicos da disciplina. Ademais, como sabemos, os imperativos antropológicos são constitutivos da condição humana, ao passo em que os princípios metodológicos são orientações de pesquisa. Os imperativos são os quatro primeiros; os princípios os seis últimos. Eles não podem ser dissociados em razão da condição ambivalente e circular que posiciona o homem como objeto de investigação do próprio homem. Vejamos, então, os imperativos (1,2,3 e 4) e os princípios (5,6,7,8,9 e 10). 
1. O primeiro imperativo antropológico a definir o programa de pesquisa da Antropologia Filosófica advém da necessidade espontânea e universal do homem quanto a interrogar-se permanentemente sobre sua própria origem e natureza. $\mathrm{O}$ homem não consegue, e nem poderia, abster-se de formar uma autoimagem de si. Ele está naturalmente obrigado a tal. Helmuth Plessner associava este imperativo natural à posição excêntrica (Exzentrische Positionalität) ocupada pelo ser humano no reino animal. Ao desenvolver a habilidade de estabelecer uma distância de si para consigo próprio, o homem torna-se capaz de refletir simbólica e racionalmente sobre sua condição. Ele não apenas objetifica-se, como interpreta-se desde um ponto de vista exterior, crítico e descentrado. A posição excêntrica como caractere singular à condição humana opera mediante a distinção entre ser-corpo (Leibsein) e ter-corpo (Köperhaben) ${ }^{11}$. Somente o homem seria capaz de exercer esta dupla condição. Tal capacidade de auto-objetivação e autodistanciamento - ver-se como um objeto que tem corpo - embora natural e espontânea, tornara-se sistemática e metódica com o advento da Antropologia Filosófica.

Ao sistematizar a habilidade natural de autodistanciamento, o programa de pesquisa da Antropologia Filosófica pôs o homem sob a condição simultânea de sujeito e objeto da ação investigativa. Ambos, objeto e investigador, passaram a encerrar-se

11 A distinção entre os substantivos Körper e Leib é um dos problemas fundamentais da Antropologia Filosófica Alemã. Ambos, em português, são traduzidos univocamente pelo substantivo corpo, porém, designam experiências distintas. Por Körper designa-se o corpo enquanto objeto empírico-científico de observação, dissecação e exame sistemático. O Körper tem disponibilidade biológica, física, química ou médica. Sua percepção depende do treinamento ascético de distanciamento, como ocorre com os jovens médicos que aprendem a controlar seu asco diante do exame anatômico dos cadáveres. O Körper designa, portanto, o corpo como uma coisa. Como tal, não coincide com a identidade corpórea e sensorial do eu. Contrariamente, é alheio a vivência sensível desta identidade. Como Körper, posiciono-me como objeto de auto-observação. Já o substantivo Leib, por oposição, denota as experiências sensíveis do eu. Ele admite o caráter teológico, simbólico, poético, emocional e espiritual do corpo vivo. É nessa dimensão corpórea, o Leib, que se registram a dor, a alegria, a fé, a vergonha, o amor, e todas as modalidades anímicas, morais e estéticas. Por isso, é o Leib quem responde pela dignidade do corpo. Cf. KRÜGER, H-P. “Die Körper-Leib-Differenz von Personen: Exzentrische Positionalität und homo absconditus". DZPhil, Akademie Verlag, 59. Potsdam. pp. 577-589. 2011. 
num só campo de percepção. Em razão desta habilidade imperativa de autopercepção crítica, o método fenomenológico revelouse o mais apropriado para o estudo de certos caracteres humanos como, por exemplo, a associação entre gestualização corporal e fala, ou as habilidades motrizes da kinefantasia (Gehlen, 1940).

Outros estudiosos como Karl Löwith (1977) e Gerhard Arlt (2008) enfatizaram igualmente a autoconsciência humana como fator determinante para o advento da Antropologia Filosófica. Arlt, por exemplo, advertiu-nos que a autoconsciência produziria necessariamente a autointerpretação. A história dos feitos humanos, seus símbolos, saberes e civilizações seria, antes de tudo, uma história da autocriação enquanto resultado da autocompreensão que o homem tem de si, ou seja, tratar-se-ia "cada vez de uma autocompreensão específica na qual dar[se-ia] uma tensão entre uma autoimagem normativa e a realidade vivida cada vez diversa"(Arlt, 2008, p.9). Daí que toda Filosofia histórica das civilizações não possa prescindir de uma Antropologia Filosófica da autoimagem dos povos.

Landmann, seguindo a interpretação de Gehlen, entende que a necessidade espontânea de autocompreensão advém da consciência de incompletude e imperfeição que acompanha o homem (o "ser de carências"). Esta necessidade atuaria como um elemento permanente de autocriação, de modo a torná-lo "sempre aberto e moldável". Segundo Landmann, "a imperfeição do homem é a que, em compensação, impulsiona à autocompreensão que diz a ele como pode se aperfeiçoar" (Landmann, 1961, p. 9).

2. O segundo imperativo antropológico de investigação da Antropologia Filosófica fora apontado por Karl Löwith como o "logos do próprio anthropos" (Löwith, 1977, pp. 243-252. Vol. 7). O princípio do logos como origem de toda ciência do homem - seja ela mítica, teológica, científica ou filosófica — nos revelaria a Antropologia como uma ciência da autoconsciência. Para o autor, este princípio seria fundamental porque:

a Antropologia entendida como o logos do homem constitui o sentido original; pois, se o homem não tivesse um logos em si mesmo, isto é, inteligência e linguagem, tampouco poderia existir uma ciência a respeito dele (Löwith in Gadamer \& Vogler, 1977, Vol.7, p. 243). 


\section{É por ter um "logos em si mesmo" que o homem está apto a compreender-se}

"como tal e na totalidade", isto é, como ser em si e como ser imerso na "totalidade do ser" (o universo). A compreensão do lugar desta Antropologia Filosófica dentre as demais ciências - a Antropologia biológica e médica, por exemplo - requer dela o mesmo atributo antropológico natural à condição humana: requer a consciência da totalidade do ser. Como assinala o autor:

Somente com esta pergunta abrangente acerca da relação entre o homem e o mundo a Antropologia se torna filosófica. Esta relação com o mundo não pode ser reduzida a uma relação unilateral do homem com o mundo, pois isto significaria que somente o homem — e não também o mundo - seria decisivo para esta relação. Impõe-se, porém, a pergunta: como se pode saber algo acerca da totalidade do ser e do mundo sem referência ao homem, o qual tem uma autoconsciência de si mesmo e uma consciência da totalidade? $\mathrm{Na}$ medida em que o homem é o ponto de partida e de referência para o conhecimento de todo o ser, parece que a Filosofia necessariamente deve reduzir-se e referir-se a ele. As três perguntas de Kant - que posso fazer? que devo fazer? que posso esperar? — reúnem-se num interrogativo fundamental: que é o homem?[...] Por outro lado, não podemos deixar de levar em conta que este excelente ponto de referência (o homem) constitui apenas um ponto, um micromega (um pequeno grande) na totalidade do ser, e que a consciência, um conhecimento sobre o que existe, é o que é, mesmo que o homem não o saiba. Ora, desde Descartes, este ser especial (o homem), por ser consciente de si mesmo, é considerado como o único fundamento seguro para o problema do ser em geral (Löwith in Gadamer \& Vogler, 1977, Vol.7, p.244).

O homem, segundo Löwith, por ser a origem de toda consciência, seja de si mesmo, seja do mundo que o circunda, constitui-se na referência absoluta do saber filosófico, e, portanto, da Antropologia propriamente dita. Daí que a Antropologia Filosófica seria uma réplica sistematizada da autoconsciência do homem em relação a si e ao cosmos. Neste caso, ela não se constitui apenas numa disciplina, mas numa condição fundamental da consciência do ser.

3. O terceiro imperativo antropológico diz respeito à precedência da Antropologia pré-filosófica sobre a Antropologia Filosófica. Para usarmos a feliz expressão de Michael Landmann, 
a proposição de uma Antropologia Filosófica só seria possível mediante a proposição precedente de uma Antropologia pré-filosófica (Landmann, 1961, pp. 10-38). Quer dizer, a necessidade anímica espontânea de autocompreensão e autointerpretação não depende da sistematicidade de qualquer Ciência. Neste aspecto, Keller assinala que:

Uma Antropologia Filosófica nesse sentido deve indicar aos fatos empíricos (aos elementos experimentáveis e aparências da vida humana) sua possibilidade e seu "lugar necessário" no todo do ser humano, bem como fundamentar justamente a partir dele, a possibilidade de sua experiência [...] A Filosofia sempre se caracterizou pela indagação a respeito das condições de possibilidade tanto daquilo que o homem imediatamente é e faz na vida "pré-filosófica", como daquilo que encontra no mundo simplesmente dado. (W. Keller, in Gadamer \& Vogler, 1977, Vol.6, p.8).

Como podemos perceber, a tese kantiana da Antropologia pré-filosófica funda-se no princípio scheleriano da precedência do mundo da vida sobre a sistematicidade da Filosofia. Esta tese radica suas raízes na fenomenologia de Husserl e no neo-vitalismo de Hans Driesch e Ludwig Klages. Keller, neste excerto, situa a Antropologia Filosófica no terreno de uma fenomenologia porque quer evitar decantações ontológicas similares àquelas inventariadas por Arlt (vide o item 6, a seguir). A Antropologia pré-filosófica, uma vez levada a sério, advoga a primazia da experiência do ser sobre a arbitrariedade poiética, utópica ou normativa das filosofias do homem. Assim, é o mundo da vida que deve legislar sobre a Antropologia Filosófica, e não as filosofias do homem legislarem arbitrariamente diversas ontologias "humanistas". A Antropologia pré-filosófica é soberana sobre toda e qualquer filosofia do homem.

4. Como tal, a Antropologia Filosófica não estaria a serviço de uma dada finalidade ou mesmo de uma utilidade pré-defini$d a$. O homem pensa sua própria condição, ainda que este pensar não se faça útil à sua própria vida. Em distinção às ciências do homem (Biologia humana, Paleoantropologia e Medicina, por exemplo), a Antropologia Filosófica seria inteiramente destituída de objetivos e de utilidade prática. Definir-se-ia, portanto, como um "querer saber por amor ao próprio saber", ou seja, seria uma autoconsciência sem qualquer determinação teleológi- 
ca ou prática do conhecimento que ela mesma produz para si. Este caráter não-pragmático e não-útil é-nos fundamental para compreendermos as dificuldades que teríamos em instrumentalizar este conhecimento para os fins de uma Filosofia Política, por exemplo. Em verdade, estaríamos diante de um saber filosófico pouco suscetível à aplicação prática. Não obstante, todos os sistemas éticos do mundo ocidental moderno, bem como as legislações que dele derivam, pressupõem uma dada representação simbólica do humano. A este respeito, Leopoldo Prieto López (2008) demonstra-nos, seguindo as quatro interrogações de Kant, que a ética é uma disciplina que estuda o que o homem deve fazer, e tal indagação pressupõe sempre o conhecimento do que o homem é, ou seja, somente a partir da resposta acerca do que vem a ser o homem, podemos elaborar uma teoria moral, e, por conseguinte, uma Filosofia Política.

5. Até aqui, a definição da Antropologia Filosófica como uma ciência da autoconsciência livre de qualquer determinação utilitária pressupõe, implicitamente, que esta disciplina tenha um programa de pesquisa uno e regular, isto é, que seja uma forma de conhecimento dotada de unidade objetual e metódica. Max Scheler, em busca desta unidade metódica, definia a Antropologia Filosófica como uma ciência de síntese. Noutras palavras, a busca pela unidade objetual e metodológica do programa de pesquisa confere à disciplina um caráter transempírico e transcientífico, isto é, atribui a ela a figuração de um prisma sobre o qual incidiriam diversos feixes de saberes. O enfeixamento dos saberes acerca do homem - Etologia, Psicologia, Medicina, Fisiologia, Paleoantropologia, etc. - constitui a própria unidade do programa de pesquisa, porém, não do objeto de estudo.

6. A unidade do programa de pesquisa, por sua vez, reivindica a unidade e singularidade do objeto de estudo. Como sabemos, não há um consenso entre as diversas Antropologias no que diz respeito à natureza e unidade de seus respectivos objetos de pesquisa. O homem da Antropologia Cultural anglofrancesa não é o mesmo estudado pela Fisiologia antropológica de Buytendijk (1974), tampouco aquele dissecado pela neuroanatomia médica. Para superar este imbróglio objetual, é preciso compreender o homem como um projeto singular na ordem da physis, e não simplesmente concebê-lo como o pináculo de uma 
hierarquia zoológica evolutiva. Quer dizer, a Antropologia não deve ser concebida como o "último capítulo de uma zoologia" (Gehlen, 1980, p.16), tal como propõem os teóricos neodarwinianas. É preciso encontrar um ponto de vista único desde o qual possamos orientar a Antropologia Filosófica em relação às ciências empíricas e culturais do homem.

A perda da unidade objetual, como sabemos, desencadeou a produção de uma multiplicidade de proposições ontológicas arbitrárias. Referimo-nos à mixórdia babélica dos "humanismos" e das "Antropologias" conforme inventariadas por Gerard Arlt. Segundo o autor, o homem já fora definido como:

zoon, animal, ens e homo: zoon politikon e logon echon (Aristóteles); animal symbolicum (Cassirer), ideologicum (Plessner), educandum (Landmann), laborans (Arendt), rationale, vitale, naturale, fingens; ens amans (Scheler), cogitans, volens; homo sapiens (Linné), ludens (Huizinga), clausus (Elias), absconditus (Plessner), compensator (Marquard), creator (Mühlmann), anthropologicus, peccator, postfatalis (Landmann), insciens (Ortega y Gasset), curans (Scheler contra Heidegger), viator (Marcel), pictor (Jonas), patiens (v.Gebsattel, Schipperges, Frankl), existencialis (Binswanger), investigans (Luck), sexualis (Fromm contra Freud), hominans e hominatus (Landmann), caelestis (von den Steinen), rhetoricus (Kopperschmidt), cogitans, faber, legens, generator, divinans, significans, sedens, inveniens, coquens, sociologicus (Dahendorf), philosophicus, religiosus, oeconomicus etc; o ser humano etimológico (Ortega y Gasset), o mítico, o humanístico (Groethuysen), o flexível (Sennet), o administrado, o funcional (Kertész), o agente (Gehlen), o tolhido (Schulz-Hencke), o unidimensional (Marcuse), o pré-programado (Eibl-Eibesfeldt), o orante (Scheler), o que espera (Bloch), o que ri e chora (Plessner), o que joga (Schiller), o antimetafísico (Knapp), o ser sem medida (Bollnow) etc., etc (Arlt, 2008, p.13).

Esta multiplicidade ontológica não é apenas uma resposta à natureza aberta do objeto ${ }^{12}$, mas também uma consequência da não-unidade objetual dos programas de pesquisa. A

12 Quando nos referimos à natureza aberta do homem, designamos a plasticidade de sua condição existencial. É esta plasticidade que podemos observar empírica e antropologicamente nos diversos relatos que narram a história de meninos criados entre lobos e que se comportam (ou se "autocompreendem") como lobos. Uma criança radicada entre lobos, um lobo será. Igualmente, uma criança criada entre pais e pedagogos "humanistas", será "humanizada" pela leitura e pelo cultivo das artes. Daí o nome de Homo Ferus, cunhado por Carl Linnaeus em 1758. 
unidade é a conditio per quam de toda Antropologia autenticamente filosófica. Quer dizer, a condição filosófica da Antropologia realiza-se tão somente quando atendidas às exigências de uma definição ontológica original, unitária e abrangedora do ser humano (W. Keller in Gadamer \& Vogler, 1977, Vol.6, p.7). Tal definição não pode ser zoológica, relativista ou restringente.

A unidade do objeto como imperativo metodológico de investigação implica, portanto, na recusa ao dualismo cartesiano, substituído pela busca filosófico-científica da unidade corpóreo -anímica. Numa palavra, deve-se desvelar o "totum" do homem sem recorrer às reduções eidéticas tais como: "o animal racional", "o ser da linguagem" ou "o animal que anda ereto e usa as mãos".

7. Crê-se, em geral, que a Antropologia Filosófica seja uma ciência de fundamentação das demais ciências humanas, atribuindo-lhe implícita ou explicitamente esta função. Acerca deste princípio, Michael Landmann assinala que toda criação cultural encerra uma criptoantropologia, ou seja, encerra uma "concepção do homem" enquanto ideia. Tal ideia realizar-se-ia como ideal de autoformação humana. Portanto, haveria uma Antropologia Filosófica subjacente a qualquer proposição sociológica, psicológica, política, cultural ou religiosa:

Fala-se, com razão, que já está contida uma Antropologia latente nas ideias mestras e nas categorias com que lidam o pensamento e a investigação psicológicos. Isto precisaria ser explicitado e seria, igualmente, tarefa de uma Antropologia explícita e crítica, examinar, purificar, justificar e fundamentar a axiomática da Psicologia (W. Keller in Gadamer \& Vogler, 1977, Vol.6, p.7).

Keller concentra-se na relação entre Antropologia Filosófica e Psicologia ${ }^{13}$, porém seus argumentos se estendem às demais Ciências Humanas. Para ele, o papel de fundamentação que se imputa à Antropologia Filosófica não é uma evidência em si, mas uma tarefa que ainda precisa ser realizada. Vemos claramente, nesse aspecto, que tanto Landmann quanto Keller dialogam com o programa de Max Scheler quando este propõe o desvelamento das concepções antropológicas subjacentes às

$13 \quad$ Nos primeiros anos do século XX, a demarcação do campo disciplinar e investigativo da Psicologia vis-à-vis o campo da Antropologia Filosófica era precária e fluida. Basta citarmos como exemplo deste interstício disciplinar as obras de Maurice Pradines (1943-1948) e F.J.J. Buytendijk (1958). 
filosofias do homem na história (Scheler, 1926, pp. 73-77). É este desvelamento - ao tornar consciente e visível uma concepção de homem supostamente subconsciente e invisível nos seus respectivos contextos histórico-filosóficos - que dará origem à noção de Antropologia Filosófica como hermenêutica antropológica do cânone. O princípio metodológico da criptoantropologia, como assinala Marquard, é, em verdade, uma retórica de autopromoção disciplinar. Ele "encurrala" as ciências humanas de tal modo que as obriga a expor claramente suas respectivas Antropologias filosóficas ocultas.

8. Como assinala Arlt, a Antropologia Filosófica impõe a si própria a tarefa de estabelecer convenções plausíveis com a finalidade de demarcar os graus do orgânico. Neste aspecto, ela concorre com as ciências empíricas da natureza e com a biofilosofia. Tal imperativo metodológico de pesquisa parte do pressuposto segundo o qual as convenções demarcatórias devem delimitar qualitativamente o limite entre o homem e o símio, entre o orgânico e o inorgânico, entre a natureza e a cultura. Noutros termos, podemos dizer que a reconstituição arqueológica e paleoantropológica das etapas do processo de hominização na história natural da espécie depende da atividade legisladora de uma Filosofia dos graus do orgânico. Dentre tais Filosofias legisladoras, está a Antropologia Filosófica. Arlt nos alerta que:

[...] quando biólogos, paleontólogos e arqueólogos investigam e datam achados ósseos, o interesse deles direciona-se às formas primitivas de vida humana. Eles deixam-se conduzir pela pergunta: já é um ser humano ou ainda é um animal? Outros achados precisam então reforçar a suspeita de que se tratava de um ancestral humano: lareira, ferramenta, pintura mural, símbolo, etc. Quais são mesmo as características constitutivas da vida humana? Aqui começa a atividade investigativa da Antropologia Filosófica" (Arlt, 2008, p.8) [Tradução corrigida por mim].

Todas as ciências que se lançam à tarefa - muitas vezes inevitável — de demarcação convencional dos graus do orgânico produzem, voluntária ou involuntariamente, uma Antropologia Filosófica. 
9. No ensaio Homo Compensator, Marquard principia sua argumentação com uma pergunta objetiva: “Tem a Antropologia Filosófica como disciplina, especialmente a atual, o status de uma ciência empírica ou o status de uma Filosofia pura como a metafísica?" (Marquard, 2001, p.15). Para o autor, desde a sua origem, a Antropologia Filosófica fora "científica como metafísica empírica". Este lugar epistemológico ambivalente, ou, como denominou o próprio Marquard, este "status anfíbio entre metafísica e empiria" situa a Antropologia Filosófica num terreno fecundo que se esquiva das classificações binárias dos cânones da teoria da ciência. Nesta lógica, a Antropologia Filosófica, enquanto experimento científico-empírico-filosófico enseja um desafio à teoria da ciência, e não o contrário. Marquard vê esta desordem epistemológica como uma abertura que torna a disciplina um paradigma fecundo, sobretudo, porque diante de sua própria história, ela tende a se desprender do "cárcere de sua definição", tornando-se uma ideia corrente no mundo da vida:

Por isso me parece importante defender precisamente sua desordenada vida epistemológica, que para a Antropologia Filosófica resulta paradigmática e irrenunciável, e fazê-lo mediante a história de seu conceito dado que a história libera os conceitos do cárcere de sua definição e do correcional de um status inequívoco: o histórico põe fim à domesticação do que, todavia, fora sistemático para despertá -lo à vida. (Marquard, 2001, p.16)

Parece-nos claro que Marquard conceba o hibridismo epistemológico da Antropologia Filosófica como uma conquista irrenunciável, quase como uma poética.

10. O décimo item refere-se ao princípio metodológico segundo o qual não há Antropologia Filosófica sem uma Filosofia da Natureza (Plessner, ano, p.26). Literalmente: "ohne Philosophie der Natur keine Philosophie des Menschen", isto é, "sem uma Filosofia da natureza, nenhuma Filosofia do homem". Esta sentença encerra o caráter naturalista da Antropologia Filosófica. Quer dizer, seu caráter radicalmente contrário à Filosofia da História.

A exposição dos imperativos antropológicos e dos princípios metodológicos do programa de pesquisa da Antropologia Filosófica pode ser assim resumida no seguinte quadro: 


\section{O PROGRAMA DE PESQUISA DA ANTROPOLOGIA FILOSÓFICA: IMPERATIVOS ANTROPOLÓGICOS E PRINCÍPIOS METODOLÓGICOS DE INVESTIGAÇÃO}

\begin{tabular}{|c|c|}
\hline \multirow{4}{*}{ 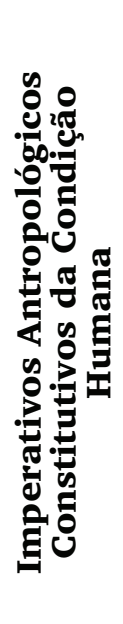 } & $\begin{array}{l}\text { 1. Necessidade espontânea e universal de autoquestio- } \\
\text { namento do homem sobre sua própria origem e natu- } \\
\text { reza. Necessidade de constituição de uma autoimagem; } \\
\text { imperativo de autocompreensão e autocriação. }\end{array}$ \\
\hline & $\begin{array}{l}\text { 2. Ciência da autoconsciência (mítica, teológica, cientí- } \\
\text { fica ou filosófica). Investigação sistemática da autocons- } \\
\text { ciência. Consciência da totalidade do ser. }\end{array}$ \\
\hline & $\begin{array}{l}\text { 3. Precedência da Antropologia pré-filosófica sobre a } \\
\text { Antropologia Filosófica. Precedência do mundo da vida. } \\
\text { Primazia da experiência do ser sobre a arbitrariedade } \\
\text { poiética, utópica ou normativa das filosofias do homem. }\end{array}$ \\
\hline & $\begin{array}{l}\text { 4. Ausência de finalidade ou mesmo de utilidade prática } \\
\text { pré-definida. }\end{array}$ \\
\hline \multirow{6}{*}{ 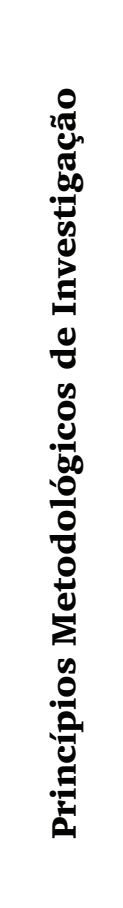 } & $\begin{array}{l}\text { 5. Imposição de um programa de pesquisa dotado de } \\
\text { unidade objetual e metodológica. Caráter transempírico } \\
\text { e transcientífico das investigações. Programa empírico- } \\
\text { fenomenológico de pesquisa. }\end{array}$ \\
\hline & $\begin{array}{l}\text { 6. Unidade e singularidade do objeto, reconhecido como } \\
\text { projeto singular na ordem da physis. Recusa ao dualismo } \\
\text { cartesiano. Recusa do evolucionismo darwinista. }\end{array}$ \\
\hline & $\begin{array}{l}\text { 7. Imposição de um programa de detecção da criptoan- } \\
\text { tropologia das ciências humanas, das religiões e da pró- } \\
\text { pria Filosofia. }\end{array}$ \\
\hline & $\begin{array}{l}\text { 8. Estabelecimento de convenções biofilosóficas cuja finali- } \\
\text { dade é delimitar qualitativamente o limite entre o homem } \\
\text { e o símio, o orgânico e o inorgânico, a natureza e a cultura. } \\
\text { Antropologia da hominização. }\end{array}$ \\
\hline & $\begin{array}{l}\text { 9. Hibridismo epistemológico. Ciência metafísica empírica; } \\
\text { "status anfíbio entre metafísica e empiria". }\end{array}$ \\
\hline & $\begin{array}{l}\text { 10. Assimilação de uma Filosofia da Natureza como funda- } \\
\text { mento de pesquisa e como negação da Filosofia da História. }\end{array}$ \\
\hline
\end{tabular}




\section{CONCLUSÃO}

O "humanismo" e as filosofias do homem estão ancorados numa Filosofia da História. Contrariamente, a Antropologia Filosófica está ancorada numa Filosofia da Natureza. Portanto, em contraposição ao que sustenta parte significativa da bibliografia, "humanismo" e Antropologia Filosófica constituem programas de pesquisa absolutamente antitéticos. Em verdade, negam-se mutuamente. Cada qual se institui acadêmica e programaticamente como negação do outro. O primeiro compreende o homem a partir de um programa ideológico de transformação do mundo, isto é, concebe o homem como ideia, conceito e utopia (o novo homem). O segundo concebe o homem como realidade, natureza e deficiência somática. $\mathrm{O}$ humanismo serve aos projetos ideológicos de mobilização política e de incitação à soteriologia revolucionária; a Antropologia Filosófica não admite qualquer finalidade prática. Ambos têm história conceitual, trajetória etimológica e programas disciplinares absolutamente dissociados.

Em verdade, a ideia de uma Antropologia Filosófica em sentido lato, isto é, como hermenêutica do cânone filosófico, se dera em razão de uma leitura unilateral dos textos de Max Scheler intitulados "Para a Ideia do Homem" (1915) e "Homem e História" (1926). Scheler entendia que o pleno desenvolvimento de uma Anthropologie no sentido estrito deveria ser precedido por uma Antropologia em sentido lato, isto é, deveria partir de uma história da consciência de si do homem segundo as diversas tradições filosóficas, míticas e teológicas do Ocidente. A reconstrução sintética de tais modos de autoconsciência histórico-espiritual, portanto, seria a primeira tarefa da Antropologia Filosófica como lugar da unidade-síntese. Reconstruir esta narrativa seria um procedimento que nos faria tomar consciência das categorias tradicionais que nos dominam de forma inconsciente, ou seja, seria uma forma de tornar evidente à consciência os modos de autocompreensão do homem na história, de maneira que pudéssemos "nos libertar lentamente" ao conhecermos "com exatidão" a "origem histórico-espiritual" (Scheler, 1986, p.74) de tais modos. Scheler propõe que faça- 
mos tabula rasa destas tradições para que elas possam emergir à consciência. Esta tarefa terapêutica de reconstrução dos modos da autoconsciência do homem fora interpretada por grande parte dos autores da Antropologia Filosófica lato sensu como tarefa única e definitiva desta disciplina. E o que é mais crítico: estes autores tendiam a julgar axiologicamente esse processo histórico de autocompreensão como "verdadeiro" ou "ilusório", "progressivo" ou "degenerativo". Desta leitura errônea e unilateral, surgiram muitos dos "humanismos" dos manuais. Para Scheler, contudo, a reconstrução terapêutica deveria ser realizada segundo um princípio de objetividade - a tabula rasa o qual dispensaria de antemão qualquer juízo axiológico.

No que diz respeito à comparação da Antropologia Filosófica com a Antropologia franco-bretã, a diferença é indubitável. A pergunta proferida pela cultural anthropology e pelo estruturalismo de Levi-Strauss, por exemplo, diz respeito à diversidade cultural e etnológica dos seres humanos. Importa para a Antropologia franco-anglofílica a diversidade das formas culturais humanas. Já a pergunta proferida pela Antropologia Filosófica diz respeito aos caracteres universais que conferem unidade ao fenômeno humano, a despeito das diferenças culturais. Por esta razão, Gerhard Arlt afirmou que, "do ponto de vista do alemão engajado", a Antropologia Estrutural de Levi -Strauss "se apresenta antes como uma paródia etnológica da Antropologia Filosófica", uma vez que "soa estranha e perdida a referência ao 'espírito humano' como substância responsável última” (Arlt, 2008, p.17).

Se observarmos desde a perspectiva da "Filosofia da Existência" de Karl Jaspers e Martin Heidegger, veremos que a ontologia analítico-existencial do ser opera a partir do registro de uma diferença onto-teológica do homem vis-à-vis o animal. Esta diferença onto-teológica nega-se a compreender o homem a partir de uma Filosofia da Natureza. Portanto, não pode ser confundida com a Antropologia Filosófica em qualquer dos sentidos (lato ou estrito).

A Antropologia Filosófica é, portanto, um paradigma de investigação filosófica. Como tal, ela tem um cânone obrigató- 
rio de autores, uma história disciplinar, um conjunto de princípios metodológicos de trabalho e um objeto incontroverso de investigação. Tratá-la de forma indiscriminada é ignorar sua história disciplinar e seu programa de pesquisa.

\section{Referências}

AGOSTI, Hector P. Condições Atuais do Humanismo. Rio de Janeiro, Paz e Terra. 1970.

ARLT, Gehard. Antropologia Filosófica. Rio de Janeiro, Editora Vozes. 2008.

BUYTENDIJK, F.J.J. O Homem e o Animal. Ensaio de Psicologia Comparada. Lisboa, Livros do Brasil. Sem data (1958).

BUYTENDIJK, F.J.J. Prolegomena to an Anthropological Physiology. New York, Duquesne University Press. 1974.

CASMANNS, OTTO. Psycologia Anthropologica Sive Animae Humanae Doctrina. 1594-1596. [Disponível no Google Books.]

CASSIRER, Ernst. Ensaio Sobre o Homem. Introdução a uma Filosofia da Cultura Humana. São Paulo. Martins Fontes. 2005.

DILTHEY, Wilhelm. Introdução às Ciências Humanas. Tentativa de uma Fundamentação para o Estudo da Sociedade e da História. Rio de Janeiro, Forense Universitária. 2010. [Tradução e Prefácio de Marco Antônio Casanova]

DILTHEY, Wilhelm. Teoria das Concepções de Mundo. Lisboa, Edições 70. 1992.

ENNEMOSER, J. Anthropologische Ansichten oder Beiträge zur Bessern Kenntniss des Menschen. 1828. [Disponível no Google Books.]

ETCHEVERRY, Auguste. O Conflito Actual dos Humanismos. Porto, Tavares Martins. 1975.

FEUERBACH, Ludowig. A Essência do Cristianismo. Lisboa, Fundação Calouste Gulbenkian, 2001.

FISCHER, Joaquim. Philosophische Anthropologie. Eine Denkrichtung des 20. Jahrhunderts. Verlag Karl Alber Freiburg, München. 2009.

GADAMER, H.G.; VOGLER, P. (orgs.) Nova Antropologia. 7 vols. [Os vols. $6^{\circ}$ e $7^{\circ}$ estão dedicados à Antropologia Filosófica]. São Paulo, Epu-Edusp. 1977

GEHLEN, Arnold. El Hombre. Su Naturaleza e su Lugar en el Mundo. (2 ed.). Salamanca, Ediciones Sígueme. 1980.

GROTHUYSEN, Bernard. Antropologia Filosófica. (2 $\left.{ }^{\mathrm{a} e d}\right)$. Lisboa, Editorial Presença. 1988. 
HABERMAS, J. Philosophische Anthropologie, In: Fischer Lexikon Philosophie. Frankfurt a. M., Fischer. 1958.

HEGEL, G.W.F. Enciclopédia das Ciências Filosóficas III. A Filosofia do Espírito. São Paulo, Edições Loyola. 2011.

HEIDEGGER, Martin. Carta sobre o "Humanismo". Lisboa, Guimarães Editores.1987.

HEIDEGGER, Martin. Kant y el Problema de la Metafísica. México, Fondo de Cultura Economica. 1996.

HERDER, J.G. Ideas para una Filosofía de la Historia de la Humanidad. Buenos Aires, Losada. 1959. (1784-1791)

HERDER, J.G. Também uma Filosofia da História para a Formação da Humanidade. Lisboa, Antígona. 1995. (1774)

HUNDT, Magnus. Anthropologicum de hominis dignitate, natura et proprietatibus. 1501. Disponível em: http://digital.zbmed.de/ physische anthropologie/content/pageview/676430. Acesso em 29/06/2016.

KANT, I. Gesammelte Schriften. Akademie-Ausgabe (AA). Königlich Preussische (Deutsche) Akademie der Wissenschaften (Editora/ Hrsg) Berlin: de Gruyter, 1922, Bd. X. pp. 145. Disponível em https://ia600201.us.archive.org/8/items/kantsgesammeltes10kant/ kantsgesammeltes10kant.pdf. Acesso em 05/07/2016.

KANT, Immanuel. Antropologia de um Ponto de Vista Pragmático. São Paulo, Iluminuras. 2009.

KELLER, W. Antropologia Filosófica - Psicologia - Transcendência: O problema da relação entre Psicologia e Antropologia Filosófica. In: GADAMER, H.G.; VOGLER, P. (orgs.) Nova Antropologia. 7 vols. [vols. 6: Antropologia Filosófica I, pp. 1-27] São Paulo, Epu-Edusp.1977.

KRÜGER, H-P. "Die Körper-Leib-Differenz von Personen: Exzentrische Positionalität und homo absconditus". DZPhil, Akademie Verlag, n.59. Potsdam. pp. 577-589. 2011.

LANDMANN, Michael. Antropologia Filosófica. U.T.E.H.A. Mexico, D.F. 1961.

LANDMANN, Michael. De Homine. Man in the Mirror of his Thought. Michigan, Aplied Literature Press. 1962 (1979).

LANDMANN, Michael. Fundamental Anthropology. Center for Advanced Research in Phenomenology \& University Press of America, Washington D.C. 1982.

LOPEZ, Leopoldo Prieto. El Hombre Y El Animal. Nuevas Fronteras de la Antropología. Mardrid, BAC. 2008.

LÖWITH, Karl. Considerações em Torno da Problemática de uma Antropologia Filosófica. In: GADAMER, H.G.; VOGLER, P. (orgs.) Nova 
Antropologia. 7 vols. [Vol. $7^{\circ}$, pp.243-252]. São Paulo, Epu-Edusp. 1977.

LUKÁCS, Georg. História e Consciência de Classe. São Paulo, Martins Fontes. 2003.

MARQUARD, O. "Zur Geschichte des philosophischen Begriffs "Anthropologie" seit dem Ende des 18. Jahrhunderts" in: Schwierigkeiten mit Geschichtsphilosophie, Frankfurt (Suhrkamp), pp.122-144. 1982.

MARQUARD, Odo. "Sobre la Historia del Concepto Filosófico de 'Antropología' desde Finales del Siglo XVIII". In: Odo Marquard. Dificuldades Con La Filosofía de La Historia. Ensayos. Valencia. PréTextos. 2007. [pp. 133-158; Notas de fim: pp.232-268].

MARQUARD, Odo. Filosofia de la Compensacíon. Escritos sobre Antropologia Filosófica. Barcelona-Buenos Aires-Mexico, Paidós Studio. 2001.

NOGARE, Pedro Dalle. Humanismos e Anti-Humanismos. Introdução à Antropologia Filosófica. (10ªed.). Petrópolis, Vozes. 1985.

PANNENBERG, Wolfart. Anthropology in Theological Perspective. The Westminster Press, Philadelphia. 1985.

PLESSNER, Helmuth. Die Stufen des Organischen und der Mensch. Einleitung in die Philosophische Anthropologie. Walter de Gruyter. Berlin/New York. 1975.

PRADINES, M. Traité de Psychologie Générale.(3 Vols.). Paris. Presses Universitaires de France. 1943-1948.

SARTRE, J.P. O Existencialismo é um Humanismo. Trad. Vergílio Ferreira. Lisboa, Editorial Presença. 1946 (1970).

SCHELER, Max. "Homem e História". In: SCHELER, Max, Visão Filosófica do Mundo. São Paulo, Editora Perspectiva. 1986 (1926). pp.73-100.

SCHELER, Max. A Posição do Homem no Cosmos. Rio de Janeiro, Forense Universitária. 1928 (2003).

SCHOPENHAUER, Arthur. Sobre a Vontade na Natureza. Porto Alegre, L\&PM, 2013. 